\title{
The Present Situation and Teaching Reform of Art Design Specialty
}

\author{
Hong Li \\ Department of Art, Science and Technology College Gannan Normal University, Ganzhou 341000, China \\ lihonggn@126.com
}

Keywords: teaching reform of art; design practice teaching; reform of basic theory of art design.

\begin{abstract}
The teaching reform of art design is the need of the development of the times. The teaching reform of art design specialty must proceed from the reality of art design and strengthen the operation skill based on theory teaching, practice other main practice links, get rid of the old ideas of design education, copy the present situation, and perfect the purpose of professional teaching and the practicability of professional course teaching. Under the background of deepening the education and teaching reform, some educators of art and design have neglected the teaching reform of the basic theory course of art design in the course of teaching reform, and still use the inherent teaching method to carry on the teaching. Basic theory and professional theory, and professional practice are disjointed, lacking coherence and progressiveness.
\end{abstract}

\section{The Importance of the Basic Theory of Art and Design}

Art design is neither pure art nor pure science and it is a comprehensive subject. Therefore, the teaching of art design cannot be traditional technique teaching, but it should be a comprehensive teaching of multi - disciplinary cross, and its teaching mode should based on heuristic education method. In the process of talent training, the teaching of the basic theory course of art design is essential. Structure should have the characteristics of system and comprehensiveness. The study of art basic theory course will play a key role in the synthesis and systematization of its knowledge structure. In addition, it can help and guide its higher level of professional study, make it fully grasp the relevant art theory knowledge, have strong creativity and rational thinking ability.

\section{An Analysis of the Present Teaching Situation of the Basic Theory Course of Art Design Specialty}

According to the author's teaching experience, the basic theory course of art design specialty includes basic theory compulsory course, Chinese and foreign art history and architecture history, as well as basic theory elective course, art appreciation and Chinese and foreign architecture appreciation courses. These courses are of great significance for improving students' artistic literacy and enhancing their aesthetic taste. The study of these courses can lay a good theoretical foundation for students and make them have a relatively wide range of knowledge and rich theoretical reserves.

\section{Curriculum Cohesion Relationship}

At present, the major of art design has become a common specialty in various colleges and universities. Art design has experienced the course from industrialized society to information society, but with the rapid development of the times, the original teaching mode of art design can no longer adapt to the development of society. It is urgent to change the traditional teaching mode, explore new teaching methods, make art design keep up with the pace of the times and serve people better. In order to carry out new teaching reform, we must first understand the present situation of art and design education. Only when we really understand this point, we can make clear the direction of art design reform. Present art design education to sum up, there are two points: Ideas are old. Although this kind of imagination is not a major phenomenon, the current education in some colleges and universities can modeled on the teaching mode of 10 years ago. The teaching 
materials have used for several years without any change, and the ideas are relatively conservative and obsolete. Do not know what kind of talent is needed in the current society, cannot keep pace with the times. Think about how the students can adapt to the society and the development of the times. Art design is the product of the development of the times, is the pace of the times, such education can said to be a failure of education. We all know that some European and American countries have relatively high level of design, many colleges and universities are also aware of this point, so some schools blindly introduce advanced education methods, educational models, think that this can improve their design level. Is it possible to improve our design? Each course should have its own foundation. It is impossible to adapt to our development by looking for apparent consistency (using the course name and class time arrangement) from its own foundation. In basic teaching, students' ability of innovation and thinking, as well as their ability to understand visual language and grasp things, are fully cultivated. The cultivation of these abilities plays a very important role in the future professional course study. In addition, in the teaching process, the school should strengthen the laboratory construction, make the students have enough practical opportunity, let the students do in the study, learn in the doing, improve the students' practical ability, master all kinds of problems in the practical work. According to the requirements of employing units for applied talents, students can master the basic principles and methods of art design organization, make students master engineering cost accounting and project budget under the condition of market economy. Methods of final accounts and knowledge of engineering claims, to further enhance students' market awareness and engineering Economic consciousness. The specialty of art design is very practical. The education of professional basic theory is the foundation of promoting the healthy development of the subject. It is the foundation of the students' future development to educate the students from the creative thinking and the idea thought. At the same time, we attach importance to the pattern design and the form creativity of the professional design foundation. Design meaning and professional course design management, the most important thing in training the knowledge of design practice is that the basic course of the major linked with the major that the students have learned, so that the students can participate in the applied design practice of their major. Design practice is an indispensable part of the design education, and the purpose of the design is to design. It is necessary to serve people and adapt to the needs of market development. We must make this course through careful investigation and study. According to the characteristics of professional education, emphasize the practical and practical nature of the professional course teaching and theoretical teaching, focus on the cultivation of technical applied design talents, combined with the provincial situation,

The school situation and the actual demand of the society for the talents of art and design should adjusted in the teaching of specialized courses and the contents of theoretical teaching, and the practicability should be emphasized in the course of teaching and practice. So when you set up a design studio and a professional practice base, or make use of a vacation to make students go to the society to actually design for their own professional counterparts, so that students can understand what knowledge they still have to master and what they need to improve. This may be in the next semester in the process of learning will targeted, can better master professional knowledge. Some of our students, who do not know how to learn in university or what they can do after graduation, have certain blindness. Through the combination of theory and practice, students can really understand the needs of society.

\section{Reform Measures of Basic Theory Course Group Teaching Method for Art Design Specialty}

In order to meet the needs of applied design talents in modern society, the teaching method of basic theory course of art design specialty should reformed accordingly with the demand of society.

\subsection{Optimization of course setup}

First, to proceed from the actual situation of students, teaching according to their aptitude, the implementation of segmented teaching. The basic theory of art design taught to students who have 
just entered the university. They have not experienced in-depth professional study. The teaching of basic theory courses can divide into three categories: excellent, medium and poor, according to the students' interest in the course and their ability to accept theoretical knowledge. The proportion of students at the middle level is the largest. In view of this situation, the teacher can divide the teaching content of each class into three parts according to the professional needs, improving and innovating. For the students with poor learning and understanding ability, they are required to master the most basic theoretical knowledge, while the middle level students are required to stimulate their interest in learning and improve their autonomous learning ability based on mastering basic theoretical knowledge. For outstanding students, emphasis should place on cultivating their innovative ability. Second, adhere to the people-oriented concept, respect students, the initiative of development will handed over to the students. Through the accumulation of long-term teaching experience, the author finds out that the main task of the educators in colleges and universities is to teach students self-study while imparting knowledge. In the course of teaching, the author changed the teaching method based on explanation, but used the heuristic teaching method, which is based on the students' autonomous learning ability, to establish the main position of the students in the teaching link, and to provide the students with a good learning atmosphere. Finally, make clear the teaching aim and the study request, establish the clear study goal: launch the teaching activity around the teaching aim, use the positive teaching method to stimulate the student's study interest, encourage the student to realize the study goal and strive hard. This requires teachers to teach in the course of teaching with the idea that the basic theory is to serve professional theory and professional practice. Pay attention to the practical application of knowledge, according to the individual needs of different majors, the purpose is to cultivate students' expectation psychology of professional study and to promote teacher-student interaction in the teaching process to realize teachers' teaching aim.

\subsection{Renew the teaching idea and teaching content}

The teaching aim of the basic theory course of art design specialty is to cultivate the students' artistic accomplishment, to improve the students' artistic taste, to enrich the students' artistic theory knowledge reserve, and to carry on the targeted teaching according to the actual development needs of different majors. The inherent teaching ideas cannot meet the needs of the development of modern art design education. Only by fully understanding the needs of applied design talents in modern society, can we grasp the direction of scientific development of the reform of teaching methods of basic theory courses, and guide students to play a subjective role in the course of learning basic theory courses. It will lay a good foundation for the future professional theory study and professional technical practice, and give full play to the basic function and ladder function of the basic theory course in the teaching of art design specialty. Basic Theory course in Art Design In the course of teaching, we should not treat all professional directions equally, and we should treat them differently: in the teaching of basic theoretical knowledge to students in different professional directions, we should take into account the individualized needs of different professional development directions. For example, the courses of architectural history and appreciation of Chinese and foreign architecture in the major of environmental art design should, for the sake of professional development, strengthen the analysis of architectural examples of different styles and schools in different countries and regions in different periods of time. To deepen the students' understanding and understanding of the indoor and outdoor environment, and to impart the basic theory knowledge, make the basic theory course become the solid foundation of the follow-up professional theory course and the related specialty practice. Different types of courses, teaching content should also focus on. For example, Chinese and foreign art history, Chinese and foreign architectural history and other basic theoretical compulsory courses, teachers should pay attention to the depth of the contents taught in accordance with the professional needs. The theoretical knowledge involved explained so that students can fully understand and realize the profound connotation of these contents. The optional courses of basic theory, such as appreciation of art and architectural appreciation at home and abroad, are complementary to the contents of required 
courses. Teachers should emphasize the extensiveness and comprehensiveness of the contents taught in the teaching. The purpose of course teaching is to expand the students' knowledge of art theory and to improve their artistic accomplishment, artistic taste and appreciation ability.

\subsection{Reform teaching methods and means}

The previous teaching methods of the basic theory course for the major of technical design: before class, the teacher prepares the teaching content according to the content of the textbook; in class, the teacher explains the teaching content in the form of indoctrination, and the students sit down and listen to the lecture. Such a teaching process makes the students' classroom learning completely passively accept the theoretical knowledge inculcated by the teacher, which leads the students to form a state of numbness without thinking or asking questions; after class, Students will not review and summarize the theoretical knowledge taught by the teacher in class. This teaching method will cause students to become inert and lose their ability to learn autonomously. This involuntary way of learning does not allow students to feel it. There is no definite learning goal and practical goal, so the students' learning is only to cope with the examination, and finally they lack imagination, innovation consciousness and innovative practical ability. With the development of science and technology, multimedia teaching equipment and computer technology have gradually penetrated into the classroom teaching of theoretical courses in colleges and universities, and have had a great impact on the educational model of related theoretical courses of art design major. With the help of high technology, teachers can make full use of multimedia equipment and the Internet to assist teaching, so that students can have an intuitive impression of the basic theoretical knowledge of art through visual communication media such as pictures and images. Teachers can help students understand and analyze the theoretical knowledge they have learned by means of images and pictures, to enhance students' interest in learning. Arouse students' initiative and enthusiasm in learning. Multimedia assisted instruction technology can help teachers to make dull basic theoretical knowledge vivid and easy to understand, to strengthen students' autonomous learning ability, to promote the interaction between students and teachers, and to activate classroom atmosphere. Increase the interest of learning theoretical knowledge.

\subsection{Flexible use of examination methods}

The examination of the basic theory curriculum group of art design majors does not require the final examination. The examination of Chinese and foreign art history and Chinese and foreign architectural history is the best way, which can urge students to master the basic knowledge of art and design. The basic theory elective course art appreciation and the Chinese and foreign architectural appreciation examination method may draw lessons from the turnover classroom form. By the teaching teacher gives the corresponding question, carries on the data collection and the arrangement work by the student under the class, The PPT courseware made to report and explain in class and the teacher supplements and deepens the contents according to the students' answers to the questions. This way can make students participate in the classroom teaching link, strengthen the communication between students and teachers, students and students, but also make students have a full understanding of what they have learned and have a deep memory.

\section{Summary}

With the development of society and the progress of science and technology, the demand for applied art and design talents in modern society urges educators in local universities to carry out the reform of teaching methods. As an important foundation of art and design major education, there are more or less problems that need to solve in the teaching of basic theory courses, which will affect the development and promotion of educational reform measures. Furthermore, it affects the training mode of applied talents in local colleges and universities. Educators have the responsibility and obligation to solve these problems, to deepen the reform of education and teaching in practical teaching work, to apply scientific teaching methods and means, and to carry out practical reforms. Make due tribute to the cause of Education by improving the present situation of Teaching. 


\section{References}

[1] Pei R. The present situation and teaching method reform of art history course in art design major. Journal of Shanxi College of Economic and Management cadres.

[2] Deng Y h. Research on the present situation and Reform Countermeasures of basic course Teaching of Art Design Major in Local Colleges and Universities. Literature and Art Life (Art China / 2011 / 12).

[3] Wang Li. A study on the Teaching Reform of basic courses for Art and Design Specialty in Colleges and Universities. Art education in 2015.

[4] Li Q dong. The present situation analysis and reform path exploration of basic course teaching of art design specialty. Art education in 2014.

[5] Liu S w. On the cultural characteristics and critical spirit of new media art [J]. Inner Mongolia Social Sciences (Chinese version).2013 (01)

[6] Fang R, Dong Bin. Spatial-temporal characteristics of the interactivity of New Media Art [J]. Journal of Anhui normal University (Humanities and Social Sciences Edition: No. 2013 / 02)

[7] Li S q. Metaphysical thinking of New Media Art [J]. Social Science of Hunan. New Media Art Design based on the combination of Art and Digital Technology

[8] L g. Contemporary art Sichuan Literature and Art Press. 2005-1-1. 